\title{
Erratum to Gehrmann and Lampe (2019)
}

The statement on the current approval status of aripriprazole in Germany is incorrect. The correct information is: In Germany and Austria, Aripriprazole is approved for the treatment of schizophrenia from the age of 15 years onward, and for up to 12 weeks of treatment of moderate to severe manic episodes (bipolar disorder) from the age of 13 years onward.

\section{References}

Gehrmann, J., Lampe, P.G. (2019). Serum Level Measurements Optimize Aripriprazole Treatment in Adolescent Patients. Zeitschrift für Kinder- und Jugendpsychiatrie und Psychotherapie, 47, 261-264. DOl https://doi.org/10.1024/1422-4917/a000637.

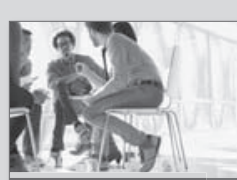

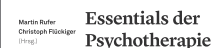

(D) hogrefe

\section{Ein authentischer Einblick} in die Alltagspraxis

Martin Rufer / Christoph Flückiger (Hrsg.)

Essentials der Psychotherapie

Praxis und Forschung im Diskurs
2020.144 S., 6 Abb., 1 Tab., Kt

$€ 24,95 / \mathrm{CHF} 32.50$

ISBN 978-3-456-85923-1

Auch als eBook erhältlich 